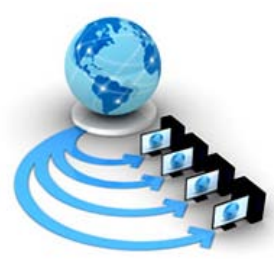

\title{
TOOLS AND TECHNIQUES FOR RETRIEVING THE HIDDEN INFORMATION OF INVISIBLE WEB
}

\author{
Hardeep Singh \\ PG Department of Computer Science, \\ BBK DAV College for Women, \\ Amritsar,India
}

\begin{abstract}
Search engines have become an important part of our daily routine. We are so much addicted to search engines, such as Google, that we cannot think of spending even a single day without them. It is a common misconception that googling a search term will reveal each and every site of the web. The fact, however, is that the typical search engines like Google, Yahoo, or Bing actually access only a tiny fraction; estimated at $0.03 \%$; of the Internet. The information resources found by such typical general-purpose search engines are referred to as the "visible web" or "surface web". The term "invisible" represents those resources that, because of their exclusion by general-purpose search engines, are not so easily found. Invisible web is a vast hidden storehouse of information that cannot be overlooked. The paper explores the importance of unfathomable information buried inside invisible web in our everyday lives. The paper also elucidates the tools and techniques used to fetch information from invisible web in different fields. Links of various web pages, that form invisible web, are mentioned along with their purpose.
\end{abstract}

Keywords: Invisible Web, Surface Web, BrightPlanet, Tor Browser, Digital Libraries

\section{INTRODUCTION}

Search engines measure their success on popularity. But due to variety of reasons, large portion of web, called the invisible web, remains impenetrable to search engines. For those who are serious searchers and are looking for the best possible information, this vast hidden store of information cannot be overlooked. The mysterious sounding invisible web was coined by a researcher in 1994 for that which was not visible to the search engines. The hidden web is used as a synonym to the invisible web. Invisible web pages are often dynamic pages within database driven sites, whereas much of the surface web consists of static pages. Search engines are well aware of the invisible web, but limitations in time and money could make it unfeasible to index all of the dynamic page possibilities. A company BrightPlanet estimated that the invisible web is $400-550$ times bigger than the surface web [1].

Table 1: Different types of Invisible Web

\begin{tabular}{|l|l|l|}
\hline Type & Description & How to Access \\
\hline $\begin{array}{l}\text { Poorly } \\
\text { Ranked Web }\end{array}$ & $\begin{array}{l}\text { Consists of information that is ranked far low in the search engine's } \\
\text { hit list may be because of limitation of search engine to show } \\
\text { number of hits, or due to unusual file type, because the web page is } \\
\text { fresh and is not linked to by some important web sites. }\end{array}$ & $\begin{array}{l}\text { Changing the search word, using } \\
\text { synonyms, changing the order of search } \\
\text { words, doubling or repeating the most } \\
\text { important search word, limiting the search } \\
\text { to specific file types such as PPT or PDF. }\end{array}$ \\
\hline $\begin{array}{l}\text { Un-indexed } \\
\text { Web }\end{array}$ & $\begin{array}{l}\text { Consists of files which could be included in search engine's indexes } \\
\text { but which are actually not due to their indexing depth and } \\
\text { frequency, or pages that are unlinked or badly designed. }\end{array}$ & $\begin{array}{l}\text { Using subject directories, industry portals, } \\
\text { going directly to where the information } \\
\text { could be found, testing different search } \\
\text { engines. }\end{array}$ \\
\hline Private Web & $\begin{array}{l}\text { Consists of pages which are prevented from being indexed by the } \\
\text { page owners by either providing the passwords or by using the meta } \\
\text { tag "noindex" which prevents the spider from indexing that page. }\end{array}$ & $\begin{array}{l}\text { Using subject directories, industry portals, } \\
\text { and searching indirectly in search engines. }\end{array}$ \\
\hline $\begin{array}{l}\text { Protected } \\
\text { Web }\end{array}$ & $\begin{array}{l}\text { Consists of pages which are prevented from being indexed for free } \\
\text { and require users to pay in order to access the resources of that web } \\
\text { site. }\end{array}$ & $\begin{array}{l}\text { Using industry portals, registering as a } \\
\text { user, and paying for services. }\end{array}$ \\
\hline Really & Consists of information that is stored in unusual formats that the & Searching indirectly in databases, \\
\hline
\end{tabular}




\begin{tabular}{|l|l|l|}
\hline $\begin{array}{l}\text { Invisible } \\
\text { Web }\end{array}$ & $\begin{array}{l}\text { spiders are not programmed to handle and cannot be indexed by } \\
\text { search engines for some technical reasons. }\end{array}$ & directories and industry portals. \\
\hline Fresh Web & $\begin{array}{l}\text { Consists of new web pages which include news, blog contributions, } \\
\text { press releases, and reports that remain invisible for weeks or } \\
\text { months. }\end{array}$ & $\begin{array}{l}\text { Using news search services, blog search } \\
\text { services, via expert's web pages and } \\
\text { monitoring subject or Web site often called } \\
\text { passive searching. }\end{array}$ \\
\hline $\begin{array}{l}\text { Disappearing } \\
\text { Web }\end{array}$ & $\begin{array}{l}\text { Consists of information that is not static and is developing and } \\
\text { changing constantly. }\end{array}$ & $\begin{array}{l}\text { Cutting the URL to get to a working web } \\
\text { page in order to start searching onwards } \\
\text { again, or checking the URL in a search } \\
\text { engine using cache }\end{array}$ \\
\hline $\begin{array}{l}\text { Non-existent } \\
\text { Web }\end{array}$ & $\begin{array}{l}\text { Consists of information that is not available on the web directly and } \\
\text { requires an expert to access information. }\end{array}$ & $\begin{array}{l}\text { Checking with someone who knows about } \\
\text { a good and important resource or } \\
\text { antacting a public library or consulting a } \\
\text { researcher. }\end{array}$ \\
\hline
\end{tabular}

The invisible web describes all pages, forums, and e-shops that are hidden and inaccessible for search engines, like Google or Bing. These pages do not use the standard HTTP/HTTPS web protocol, so they cannot be searched by using a common browser, like Chrome, Edge, or Firefox. It will be incorrect to say that invisible web is really invisible and cannot be accessed. To fetch the information stored in invisible web, there are special search engines other than traditional general purpose search engines such as Google and Bing [3]. The following table gives a list of few search engines which are good tools to access the invisible web [4].

Table 2: List of Search Engines to access Invisible Web along with their links (sorted alphabetically)

\begin{tabular}{|l|l|l|}
\hline S No. & Name & Link \\
\hline 1 & Directory of Open Access Journals & https://doaj.org/ \\
\hline 2 & Infoplease & https://www.infoplease.com/ \\
\hline 3 & RxList & http://www.rxlist.com/script/main/hp.asp \\
\hline 4 & Science.gov & https://www.science.gov/ \\
\hline 5 & The National Security Archive & http://nsarchive2.gwu.edu//search.html \\
\hline 6 & The WWW Virtual Library & http://vlib.org/ \\
\hline 7 & U.S Geological Survey & https://www.usgs.gov/ \\
\hline 8 & USA.gov & https://www.usa.gov/ \\
\hline 9 & Voice of the Shuttle & http://vos.ucsb.edu/ \\
\hline 10 & WorldCat & http://www.worldcat.org/ \\
\hline
\end{tabular}

\section{NEED AND IMPORTANCE OF STUDY}

Invisible web offers a vast array of resources and information on almost everything that one could ever imagine. The web which is visible to us; the surface web; is actually thousands of times smaller in contents and size as compared to the web that is invisible to us. A search organization named BrightPlanet, which is expert in fetching data from invisible web, reports that the invisible web includes approximately 550,000,000,000 individual documents whereas the visible web includes approximately $1,000,000,000$ individual documents [5]. According to another report the visible web is only $1 \%$ of the entire web available. The information that is tucked away in databases, or is old and outdated, or the contents of iPhone apps, or the online journals, white pages, electronic books, newspaper archives, dictionary definitions, patents court records, and private social media profiles, which any general purpose search engine is either not interested or barred from crawling forms the invisible web. Even the frequently updated or changing information, like ticket prices and job listings, are also part of the invisible Web.

\section{OBJECTIVE: TOOLS AND TECHNIQUES FOR RETRIEVING INVISIBLE WEB}

There are a number of different reasons that make invisible web very important to all who search for information on net. Moreover, the invisible web will get bigger with passage of time; therefore the techniques and tool used for accessing its resources must be explored. Depending on the information to be fetched, different parts of the invisible web can be accessed using different tools and techniques. Following are some tools used to navigate the invisible web:

- Books and Journals: Digital information which is stored in the format that is not understood by web crawlers or that resides behind a paid gateway. Such files could be opened only after downloading.

- Databases: Tabulated information related to individuals, world, climate, census etc.

- Tor Network: Websites which tend to remain concealed and include material such as unlawful porn, stolen individual records, drug associates, unspecified political rebels, terrorists and many more can be accessed using Tor (The Onion Router) browser.

\section{I BOOKS AND JOURNALS}

One of the deepest parts of invisible web is the books and journals. Accessing them using general purpose search engines; such as Google; is a difficult task [6]. There are some resources available on the web that assists to access the major part of academic books and journals. Following is 
the list of some of such resources that help to fetch online books and journals with much ease.

\section{- Google Scholar:}

Google Scholar is one of the most famous tools used for fetching scholarly records from the deepest of the invisible web. Google Scholar scans the articles published in major online journals and output the best possible results. In addition to providing access to journal publications, Google Scholar also provides the records from patents as well as records of case law results fetched from U.S. federal or State Courts that are U.S. based only. The patent database contains many remarkable findings hidden inside them that make Google Scholar a valuable invisible web harvester.

- Microsoft Academic Search:

An equivalent of Google Scholar is the Microsoft Academic Search tool provided by Microsoft. Microsoft Academic Search tool provides results that include both free and paid links of online books and journals. This quick and easy tool is much useful if only the citation and findings of the paper are desirable.

- Institute of Education Sciences:

Institute of Education Sciences; abbreviated as ERIC; is another search tool for fetching online books and journals. This tool is implemented by U.S. government's Education Department. The librarians and educators use this search tool to perform academic research and help the students to find excerpts of their work. The educational institutions or non-profit research organizations provide the results of papers and findings in full form to the ERIC search tool. Due to this reason, this easy to use and low cost search tool ERIC is very useful resource the students to gather academic information on the invisible web [7]. Moreover, the citations are always available for free and the results show straight links to the source.

\section{- JSTOR:}

JSTOR stands for Journal Storage is a digital library that was founded in 1995. JSTOR is an all-inclusive search engine for digitized back date as well as current issues of online academic books and journals. JSTOR provides search results from almost 2000 journals. The major objective of this non-profit search engine is to help the researchers and students by providing huge collection of scholarly articles. Currently, JSTOR is accessible to more than 8,000 educational institutions in more than 160 countries worldwide.

- Genamics:

Genamics is another search tool used fetch free of cost available books and journals. Genamics is dedicated to empowering the researchers with the latest and state-of-theart solutions. It allows searching of records either Title wise or ISSN wise. Genamics provides a Category Browser which assists to fetch the records category wise.

In addition to these, there are other valuable resources that can be used by academic researcher to fetch information buried inside the invisible web. They include iSeek, Digital Library of the Commons, and Infomine.

Table 3: List of resources that assist to fetch online journals and books along with their links (sorted alphabetically)

\begin{tabular}{|l|l|}
\hline Service Name & Link \\
\hline Digital Library of the Commons & http://dlc.dlib.indiana.edu/dlc/ \\
\hline Genamics & http://journalseek.net/ \\
\hline Google Scholar & https://scholar.google.co.in/ \\
\hline Infomin & http://infomine.ucr.edu/ \\
\hline Institute of Education Sciences (ERIC) & https://eric.ed.gov// \\
\hline iSeek & http://education.iseek.com/iseek/home.page \\
\hline JSTOR & http://www.jstor.org/ \\
\hline Microsoft Academic Search & http://academic.research.microsoft.com/ \\
\hline
\end{tabular}

\section{II DATABASES}

Without knowing the secret of uncovering some database, it is not possible to fetch information from that database. Although many databases are easily fetched by the search engines including community records, criminal databases, digitized court records etc., but still some databases are invisible to search engines and require invisible search to be fetched. The information stored inside databases include definition of words, patents, telephone numbers, laws, information about particular products, sound files, news, job ads and much more [14]. Invisible web harvesting is important to fetch information from such databases. Some of such invisible web databases are discussed as follows.

- Missing Relatives Database

Invisible web harvesting plays an important role in making people search when the child runs away or one parent leaves the family or when the family members simply lose contacts over time. In such situations, invisible web harvesting plays a vital role in tracking down those relatives. It is one of the difficult jobs and detailed data about that person is needed including birth date, residential address, full names of the names of close relatives etc. One of the invisible web harvesting tools for finding missing relatives is FamilyLink. FamilyLink [8] is an open web facility that helps to find missing relatives and to stay connected with them.

- Adoption Database

Adoption database contains records of the adopted children and the parents who gave up their children. These databases are invisible to the traditional search engines. To fetch such information there is a need to know the right registry database path. Such databases are very helpful in discovering and reuniting the children with their family members. Adoption database provides an efficient beginning for any kind of adoption research effort. The search option available on this site provides records including the name of adopted child at birth, date of birth, initial name of the birth mother, the birth place, and much more. Invisible web searching of these databases using Adoption Database website has made possible more than 4000 reunions [9]. The quantity and quality of search results obtained from this database are incredible. In addition to adoption database, there is another tool named Adoption Registry, which provides access to similar information. This registry is a free 
service for the family members who are separated by adoption. In addition to the search results, this registry provides many features such as complete privacy control, advances search features, password retrieval, pictures, abuse reporting and many more [15]. Another good search tool is called FindMe.org which is a non-profit mutual consent reunion registry. This free registry matches the adoptees with the birth family when both are interested in being found. Adoptee Connect is another useful invisible web harvester for fetching adoption records searches. It is one of the worldwide adoption reunion registries. Adoptee Connect is also launching a new DNA integrated service in fall 2017.

Table 4: List of Adoption Database along with their links (sorted alphabetically)

\begin{tabular}{|l|l|}
\hline Database Name & Link \\
\hline Adoptee Connect & https://www.adopted.com/adoptee-connect.html \\
\hline Adoption Registry & http://www.adoptionregistry.us/ \\
\hline FindMe.org & http://www.findme.org/index.cfm?fuseaction=Main\&Error=1 \\
\hline
\end{tabular}

\begin{tabular}{|c|c|c|c|c|c|c|c|c|c|c|c|c|c|c|c|c|c|}
\hline \multicolumn{18}{|c|}{$1-100$ of 10210 Records } \\
\hline & $\begin{array}{l}\text { Registration } \\
\text { \# }\end{array}$ & Status & I am & $\begin{array}{l}\text { In Search } \\
\text { of }\end{array}$ & $\begin{array}{l}\text { Adoptees } \\
\text { DOB }\end{array}$ & $\begin{array}{l}\text { DOB } \\
\text { Range }\end{array}$ & Gender & Race & $\begin{array}{l}\text { Adoptee } \\
\text { Name at } \\
\text { Birth }\end{array}$ & $\begin{array}{l}\text { City \& State } \\
\text { of Birth }\end{array}$ & $\begin{array}{l}\text { County/Province } \\
\text { of Birth }\end{array}$ & Country & $\begin{array}{l}\text { BM } \\
\text { Maiden } \\
\text { Name }\end{array}$ & $\begin{array}{l}\text { BM Name } \\
\text { at Adoptees } \\
\text { Birth }\end{array}$ & Birthfather & Hospital & $\begin{array}{l}\mathrm{Ac} \\
\mathrm{Al}\end{array}$ \\
\hline - & 00-07-0005 & $\begin{array}{l}\text { FOUND } \\
07 / 30 / 2000\end{array}$ & Adoptee & Birthmother & 10/29/1961 & $\begin{array}{l}10-29- \\
1961\end{array}$ & Female & & $\begin{array}{l}\text { Baby Girl } \\
\text { Kenyon }\end{array}$ & Oroville, CA & Butte & USA & & & & & \\
\hline - & 00-07-0006 & $\begin{array}{l}\text { FOUND } \\
\text { 02/18/2012 }\end{array}$ & Adoptee & Birthmother & 04/29/1967 & & Female & & $\begin{array}{l}\text { Mary Isabelle } \\
\text { Earley }\end{array}$ & $\begin{array}{l}\text { Unknown, } \\
\text { NC }\end{array}$ & & USA & Unknown & $\begin{array}{l}\text { Unknown } \\
\text { Age } 17 \\
\text { Student }\end{array}$ & & & \\
\hline - & 00-07-0007 & $\begin{array}{l}\text { FOUND } \\
\text { 03/10/2001 }\end{array}$ & Adoptee & Birthmother & 04/10/1966 & $\begin{array}{l}\text { 04-10- } \\
1966\end{array}$ & Female & & $\begin{array}{l}\text { Marcia Celia } \\
\text { Carroll }\end{array}$ & $\begin{array}{l}\text { Pittsburgh, } \\
\text { PA }\end{array}$ & & USA & Carroll & $\begin{array}{l}\text { Hazel } \\
\text { Maurie } \\
\text { Carroll }\end{array}$ & & & \\
\hline - & $00-07-0012$ & $\begin{array}{l}\text { FOUND } \\
07 / 30 / 2000\end{array}$ & Adoptee & Birthmother & 04/09/1963 & $\begin{array}{l}\text { 04-09- } \\
1973\end{array}$ & Male & & Steven D Lee & Ventura, CA & Ventura & USA & & & & & \\
\hline - & 00-07-0014 & $\begin{array}{l}\text { Invalid } \\
\text { email 9/03 }\end{array}$ & Adoptee & Birthmother & 07/12/1962 & $\begin{array}{l}07-12- \\
1962\end{array}$ & Female & & $\begin{array}{l}\text { Mary } \\
\text { Catherine? }\end{array}$ & $\begin{array}{l}\text { Baltimore, } \\
\text { MD??? }\end{array}$ & Unknown & USA & Unknown & Unknown & Unknown & Unknown & $\begin{array}{l}\mathrm{C}_{i} \\
\mathrm{Cl}\end{array}$ \\
\hline - & 00-07-0015 & $\begin{array}{l}\text { FOUND } \\
11 / 07 / 2001\end{array}$ & Birth Sibling & Adoptee & 02/11/1966 & & Female & & & Augusta, GA & & USA & Durham & $\begin{array}{l}\text { Cheryl } \\
\text { Laverne } \\
\text { Durham }\end{array}$ & & & \\
\hline 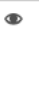 & 00-07-0016 & $\begin{array}{l}\text { FOUND } \\
\text { 05/29/2002 }\end{array}$ & Birth Sibling & $\begin{array}{l}\text { Adoptees } \\
\text { M \& F } \\
\text { Twins }\end{array}$ & 10/09/1967 & $\begin{array}{l}10-09- \\
1967\end{array}$ & $\begin{array}{l}\text { Male \& } \\
\text { Female } \\
\text { Twins }\end{array}$ & White & $\begin{array}{l}\text { Todd Scott } \\
\text { Cutler } \\
\text { \& Lauri Ann } \\
\text { Cutler }\end{array}$ & $\begin{array}{l}\text { Middletown, } \\
\text { NY }\end{array}$ & Orange & USA & & $\begin{array}{l}\text { Kay Dorothy } \\
\text { Cutler }\end{array}$ & $\begin{array}{l}\text { Donald John } \\
\text { Cutler }\end{array}$ & & \\
\hline - & 00-07-0018 & $\begin{array}{l}\text { FOUND } \\
07 / 01 / 2002\end{array}$ & Adoptee & Birthmother & 07/13/1967 & $\begin{array}{l}\text { 07-13- } \\
1967\end{array}$ & Female & & & $\begin{array}{l}\text { New } \\
\text { Orleans, LA }\end{array}$ & Orleans Parish & USA & & & & & \\
\hline - & 00-07-0021 & $\begin{array}{l}\text { FOUND } \\
07 / 28 / 2000\end{array}$ & Birth Sibling & Adoptee & 03/29/1967 & & Female & & $\begin{array}{l}\text { Baby Girl } \\
\text { Johnson }\end{array}$ & Chicago, IL & cook & USA & Johnson & $\begin{array}{l}\text { Karen Lee } \\
\text { Johnson }\end{array}$ & & & \\
\hline - & 00-07-0023 & $\begin{array}{l}\text { Invalid } \\
\text { email } \\
10 / 03\end{array}$ & Adoptee & Birthmother & $09 / 25 / 1960$ & & Female & & Unknown & Tulsa, OK & Tulsa & USA & Unknown & $\begin{array}{l}\text { Unknown } \\
\text { Age 19-21 } \\
\text { Student }\end{array}$ & Unknown & $\begin{array}{l}\text { St Johns } \\
\text { Hospital }\end{array}$ & $\mathrm{PI}$ \\
\hline - & 00-07-0024 & $\begin{array}{l}\text { FOUND } \\
\text { Birthfamily } \\
08 / 10 / 2000\end{array}$ & Adoptee & Birthmother & 01/10/1969 & & Female & & $\begin{array}{l}\text { Baby Girl } \\
\text { Hufifstuter }\end{array}$ & $\begin{array}{l}\text { Birmingham, } \\
\text { AL. }\end{array}$ & Jefferson & USA & Phillips & $\begin{array}{l}\text { Mary Lee } \\
\text { Phillips }\end{array}$ & Hufstutler & & \\
\hline - & $00-07-0025$ & $\begin{array}{l}\text { FOUND } \\
08 / 08 / 2000\end{array}$ & Adoptee & Birthmother & 12/25/1966 & & Female & & $\begin{array}{l}\text { Cherity } \\
\text { Isadora } \\
\text { Eisnaugle }\end{array}$ & $\begin{array}{l}\text { Springfield, } \\
\mathrm{OH}\end{array}$ & & USA & Sherrick & $\begin{array}{l}\text { Mary Ellen } \\
\text { (Sherrick) } \\
\text { Eisnaugle }\end{array}$ & $\begin{array}{l}\text { Othel } \\
\text { Eisnaugle }\end{array}$ & & \\
\hline
\end{tabular}

Figure 1: Adoption database screenshot from https://adoptiondatabase.quickbase.com

- Background Checking Database

Background checks are essential to know about new person we often meet in our personal, private or business life before forging some kind of partnership or relationship with them. Background checks are done to know the past history of individuals in many cases such as matrimonial cases, business cases, and debtor issues, pre-employment and postemployment checks or while hiring a new tenant. Invisible web background checking allows finding whether a person is addicted to alcoholism or smoking, family history, medical history, business history, police cases and educational records so that any threat is tackled with ease. Many databases available online for background checking are usually paid and cost a modest fee. Such databases can be accessed by dipping into invisible web free of cost. Data regarding individual's location, work place and even the names of the relatives can be fetched from these databases. PeopleFinders is one of such free databases which are efficient in fetching best possible information for a particular individual. Another tool, namely Intelius, provides additional information and history of the most current places the person has lived. Another service named PeekYou is efficient in fetching all the information of a particular individual from different websites, blogs, forums and social networking sites including Twitter and Facebook. In addition to these, there is another tool called Pipl that performs similar work of fetching useful records from background checking databases. The U.S. Department of Justice provides a registry named National Sex Offender Registry to check if a person is a sex offender or not [14]. Other databases for this include Criminal Searches, Criminal Check, Black Book Online, FBI, Verified Credentials, Interpol, ICC etc.

Table 5: List of Background Checking Database along with their links (sorted alphabetically)

\begin{tabular}{|l|l|}
\hline Database Name & Link \\
\hline Peoplefinders & www.peoplefinders.com \\
\hline Intelius & https://www.intelius.com/ \\
\hline PeekYou & http://www.peekyou.com/usa/district_of_columbia /_johnson \\
\hline Pipl & https://pipl.com/ \\
\hline National Sex Offender Registry & https://www.nsopw.gov/ \\
\hline Criminal Searches & http://www.criminalsearches.com/ \\
\hline
\end{tabular}




\begin{tabular}{|l|l|}
\hline Criminal Check & http://www.criminalcheck.com/ \\
\hline Black Book Online & http://www.blackbookonline.info/criminalsearch.aspx \\
\hline FBI & https://www.fbi.gov/services \\
\hline Verified Credentials & http://www.verifiedcredentials.com/get-started/ \\
\hline Interpol & https://www.interpol.int/notice/search/wanted \\
\hline ICC & https://www.icc-cpi.int/en_menus/search/ \\
\hline
\end{tabular}

\section{- Genealogy Database}

Genealogy is one of the most popular interests of individuals around the world. People are always curious to search data regarding their past ancestors. Invisible web harvesting is very beneficial in this regard. There are many invisible web databases that can provide information on this topic such as free genealogy database, local historical society database and file archives, online obituaries and birth notices, cemetery records and many more.

- Veteran Database

Maximum veterans work for nationwide government and therefore veteran research on the Web is actually very profitable. Veteran database can be fetched using invisible web resources that are not searchable by any of the traditional search engines. These invisible web resources include FOIA requests, non-profit organizations for veterans, United States veteran service webpages, historical research web pages and many more. The most impressive, free deep web directory for veteran information is the Veterans History Project. Other invisible web resources for finding information about veterans include National Archives, VetFriends, Grave Locator, Ancestry.co.uk etc.

Table 6: List of Veteran Database along with their links (sorted alphabetically)

\begin{tabular}{|l|l|}
\hline Database Name & Link \\
\hline Veterans History Project & http://memory.loc.gov/diglib/vhp/html/search/search.html \\
\hline National Archives & https://www.archives.gov/veterans \\
\hline VetFriends & https://www.vetfriends.com/search.cfm \\
\hline Grave Locator & https://gravelocator.cem.va.gov/ \\
\hline Ancestry.co.uk & http://search.ancestry.co.uk/search/category.aspx?cat=128 \\
\hline
\end{tabular}

In addition to these databases, there are other reasons for invisible web harvesting such as digging into the past about a particular location or an event. Such type of research needs several areas of invisible web to be covered including academic records, government and legal case records as well as many historical records which are concealed throughout the web and untouchable by any traditional search engines and crawlers [10].

\section{- Native and Local History}

Many organizations are involved in preserving and protecting the history of a local region. Such organizations and societies have their own online database of historical records and documents and scanned photos. These databases are unreachable by search engines and require invisible web harvesting. One of such invisible web database that is used as part of historical research is FamilySearch.org [11]. FamilySearch is supported by The Church of Jesus Christ of Latter-day Saints. It allows making connections by creating a family treasure that brings the family history to life. It also allows to made discoveries by searching individual's ancestors in millions from historical records. This website is amazingly rich with information and resources for conducting genealogy research.

\section{- Legal Records Database}

There are factually thousands of high quality legal researches databases containing case documents and court decisions exist on the Internet today, but amazingly, not even one of them could be visible through traditional search engine results. Invisible web assists to explore all such legal databases that contain records of court cases and court decisions buried out there. Some of the legal research websites that are harvested by invisible web are law school court opinion search engines, law library case databases, non-profit legal organization search tools for legal cases etc.

- Academic Database
Invisible web harvesting is required in discovering records and reports of academic research findings that are tucked away invisible inside the invisible web of databases stored on various university servers. To access such information a minimal fee is required to be paid. Many large organizations, including Google and Microsoft, provide open search engines named Google Scholar, Google Deeper Web and Microsoft Academic Research to access academic databases. These search tools assist in burrowing invisible into academic research databases and fetch out the desirable research and the findings that are not found through search engines.

\section{III TOR NETWORK}

Tor (The Onion Router) network is a network of undisclosed places or web pages which the individuals are frightened to visit or access. Websites in Tor do not have any domain or IP addresses and are completely inaccessible to search engines. In order to access the websites of Tor network, a special browser named Tor Browser Bundle should be used. This browser provides the entry point to the Tor network where the criminals, terrorists, hackers and pedophiles can pursue their trades. Tor network provides a doorway to sell and buy various daring items like drugs, firearms, explosives, forged papers, human organs etc. The websites that are present in Tor network have extension “.onion”. The three most popular .onion websites in the Tor world are Deep Web Links, The Hidden Wiki and Tor Links [12] [13]. 
Table 7: List of famous three .onion web sites along with their links (sorted alphabetically)

\begin{tabular}{|l|l|}
\hline Site Name & Link \\
\hline Deep Web Links & http://32rfckwuorlf4dlv.onion// \\
\hline The Hidden Wiki & http://zqktlwi4fecvo6ri.onion/wiki/index.php/Main_Page \\
\hline TorLinks & http://torlinkbgs6aabns.onion/ \\
\hline
\end{tabular}

\section{CONCLUSION}

Web is a vast library of resources. Just sticking with the results obtained by various general purpose search engines; such as Google; is not sufficient. With the passage of time the invisible web will definitely expand and hence there is an extreme need to study how to discover it. The paper mentions different tools and techniques needed to dig the invisible web for all the resources available. The paper highlights various strategies to touch the vast resources existing on the invisible web including journals and books, databases and Tor network. Links to access knowledge and information from different journals and books are cited. In addition to this, links to fetch databases such as missing relative database, adoption database, background checking database, genealogy database and veteran database are stated. Links of three most common .onion sites are also revealed.

\section{REFERENCES}

[1] Bright Planet, https://brightplanet.com/

[2] Sugiura, A. And O. Etzioni, Query Routing for Web Search Engines: Architecture and Experiments. 2000 WWW Conference, 2000.
[3] Raghavan, S. and H. Garcia-Molina. Crawling the Hidden Web. in 27th International Conference on Very Large Data Bases. 2001. Rome, Italy.

[4] Make use of, http://www.makeuseof.com/tag/10-search-enginesexplore-deep-invisible-web/

[5] Bergman, M.K., The Deep Web: Surfacing Hidden Value. 2000, BrightPlanet.com

[6] Deepweb Sites: https://www.deepweb-sites.com/surfanonymously-online-using-tor-browser

[7] Brophy, J. and Bawden, D. (2005), "Is Google enough? Comparison of an internet search engine with academic library resources", Aslib Proceedings, Vol. 57, No. 6, pp. 498-512.

[8] Family link, http://www.familylink.com/

[9] Adoption database, https://adoptiondatabase.quickbase. com

[10] B. Schneier. Do you want the government buying your data from corporations? http://www.theatlantic.com/ technology/archive/2013/04, April 2013.

[11] Family search, https://www.familysearch.org/

[12] P. Eckersley. How unique is your web browser? In Privacy Enhancing Technologies, pages 1-18, 2010

[13] Sui, D., Cavarlee, J., \& Rudesill, D. (2015). The deep web and the darknet: a look inside the internet's massive black box. Wilson Center, Washington.

[14] The Invisible Web, http://www.jonasfransson.com/11-theinvisible-web/

[15] Adoption Registry, http://www.adoptionregistry.us/ 